\section{The law and physician-assisted dying}

$\mathrm{F}$ or most Canadians, the arguments that began on Oct. 14, 2014, at the Supreme Court in Ottawa are about medical aid in dying. But what is really at stake in Carter et al. v. Attorney General of Canada et al. is Canadian law itself, the meaning of its guarantees, promises and injunctions.

Lawyers for and against physician-assisted death are asking the Supreme Court's justices to interpret two sections of the Canadian Charter of Rights and Freedoms: section 7 - "everyone has the right to life, liberty and security of the person," and section 15 - "equal protection and equal benefit of the law without discrimination." The result will define not only the many issues of assisted dying but also the future of Canadian law and society for years to come.

Civil libertarians argue that "life, liberty and security of the person" means we should be free to choose the time and means of our dying. Physical limitations might prevent this, so to disallow the medical termination of the fragile at a time of their choosing is discriminatory.

Justice Canada's lawyers insist that the first responsibility of society is to assure the security and protection of the person. From that perspective, it is difficult to interpret the charter's language as inviting a "right" to state-supported, medical termination. To guarantee the protection of life and then argue for the termination of life violates the charter's language and intent.

After all, this isn't about "independent" action but social participation through provincial medical services in the termination of lives that we agree aren't charter protected and aren't worthy of preserving. This worries disability activists.

Compelling society's support of a person's request to die and demanding we act upon it through provincially funded medical termination is logical, but there is no "autonomous" section in the charter. For libertarians it is implicit, a principle they use to interpret the law.

Justice Canada argues that Section 15 means what it says, insisting we support the care and rehabilitation of the fragile while prohibiting their termination, even if it is requested. What Supreme Court justices must decide is whether termination is "just" a medical procedure with no special moral import or something more.

\section{Tom Koch PhD}

Medical ethicist, Toronto, Ont.

\section{Care, compassion, respect}

$\mathrm{P}$ hysician-assisted death (PAD) is a controversial subject in Canada, but it shouldn't be. Polls show that Canadians support PAD almost as much as they support sunlight and clean drinking water. ${ }^{1}$ PAD is now legal in many jurisdictions, and we have a large body of evidence to address fears about slippery slopes.

When PAD was legalized in Europe, it did not become the default option for dying patients; it generally remained stable while palliative care grew dramatically. ${ }^{2}$ According to the Economist, the five countries that have legalized PAD are world leaders in the "[b]asic end-of-life healthcare environment,"3 while Canada sits in the middle of the pack. According to the Center to Advance Palliative Care, all three US states that have legalized PAD by statute rank in the top eight for availability of palliative care services in hospitals. ${ }^{4}$

The vulnerable do not appear to be pressured into accepting PAD - in fact, most patients who receive PAD are wealthy, educated and supported by family members and health insurance., ${ }^{5,6} \mathrm{I}$ would call them "privileged," but then I remember their suffering.

I don't support death. I enjoy my life, and I work very hard as a critical care physician to keep patients alive - when I can. But I accept that there are times when I can't. And there are times when I can keep people alive, but not in a state that they would value. I respect their right to know when they've had enough, and I don't see why they should have this right only when they are dependent on life support.

Therefore, my support for PAD is based on an ethic of care, and the desire to help people achieve the death that they want. I'm not advocating for universal PAD, but universal choice. This debate calls for humility and a willingness to listen to our patients.

\section{James Downar MDCM MHSc (Bioethics)}

Divisions of Critical Care and Palliative Care, Department of Medicine, University of Toronto. Toronto, Ont.

\section{References}

1. Most $(84 \%)$ Canadians believe a doctor should be able to assist someone who is terminally ill and suffering unbearably to end their life. Toronto: Ipsos Reid; 2014. Available: www.ipsos-na .com/news-polls/pressrelease. aspx?id=6626 (accessed 2014 Oct. 14).

2. Onwuteaka-Philipsen BD, Brinkman-Stoppelenburg A, Penning C, et al. Trends in endof-life practices before and after the enactment of the euthanasia law in the Netherlands from 1990 to 2010: a repeated cross-sectional survey. Lancet 2012;380:908-15.

3. Praill D, Radbruch L, Rajagopal MR, et al. The quality of death: ranking end-of-life care across the world. Washington: The Economist Intelligence Unit; 2010.

4. A state-by-state report card on access to palliative care in our nation's hospitals. New York: Center to Advance Palliative Care; 2011. Available: www.capc.org/reportcard/topten (accessed 2014 Oct. 14).

5. Loggers ET, Starks H, Shannon-Dudley M, et al. Implementing a death with dignity program at a comprehensive cancer center. N Engl J Med 2013;368:1417-24

6. Steck N, Junker C, Maessen M, et al. Suicide assisted by right-to-die associations: a population based cohort study. Int J Epidemiol 2014;43:614-22.

CMAJ 2014. DOI:10.1503/cmaj.141340

Editor's note: Both articles were originally posted, unabridged, on CMAJ Blogs (http://cmajblogs.com/pad) 